\title{
Elaboration and model analysis of characteristics of the flexible liner for an oil tank car
}

\author{
Viktor Katin ${ }^{1}$, Vladimir Kosygin ${ }^{2,}$, Midkhat Akhtiamov ${ }^{1}$, and Andrey Lutsenko ${ }^{1}$ \\ ${ }^{1}$ Far Eastern State Transport University, Khabarovsk, Russia \\ ${ }^{2}$ Computer Center of the Far Eastern Branch of the Russian Academy of Sciences, Khabarovsk, \\ Russia
}

\begin{abstract}
The article focuses on the original author's development - the flexible liner for a rail tank car that allows reducing the risk of leakage of hazardous liquid cargos (in particular crude oil or petroleum products) during their transportation by rail. Application of the liner allows ensuring hermetical containment of a tank car even if a barrel has any minor defects, excludes a contact of cargo with tank walls, which leads to increase in the security of hazardous liquid cargo transportation. This original development enables ensuring the safety and security of hazardous cargo transportation and minimizing its impact on the environment. The liner can also be used for increasing the service life of a rail tank car and reducing the costs of its maintenance.
\end{abstract}

\section{Introduction}

For the rail transportation of third hazard class cargos such as crude oil and petroleum products, rail tank cars are used [1]. The rail tank car fleet involved in transportation of crude oil and petroleum products, which contains more than 275 thousand units, is currently private, therefore it is complicated to control the used tank cars for correspondence to regulatory requirements.

Transportation of petroleum products plays the leading role in the rail transportation system. In 2011, 126.4 million tons of oil and petroleum products was shipped on domestic routes. Compared with 2010, in 2011 the loading of oil products increased by $4 \%$, and in 2012 this factor increased by $2.8 \%$ [2]. The total volume of transportation of oil and petroleum products by open joint-stock company "Russian Railways" amounted to 250.3 million tons in 2013. It is worth mentioning that the most part of the rail tank car fleet is operated with excess of standard service life.

\footnotetext{
${ }^{*}$ Corresponding author:
} 
More than $78 \%$ of incidents during transportation of hazardous cargos realized by open joint stock company "Russian Railways" is associated with using tank cars. In the Far Eastern Railway this factor is about $98 \%$ [3]. Moreover, $40 \%$ of these incidents are attributed to tank wagons with extended service life.

The statistical reporting analysis carried out by the authors shows that in recent years there has been a consistently high number of incidents associated with the transportation of oil and petroleum products on the Far Eastern Railway (Figure 1).

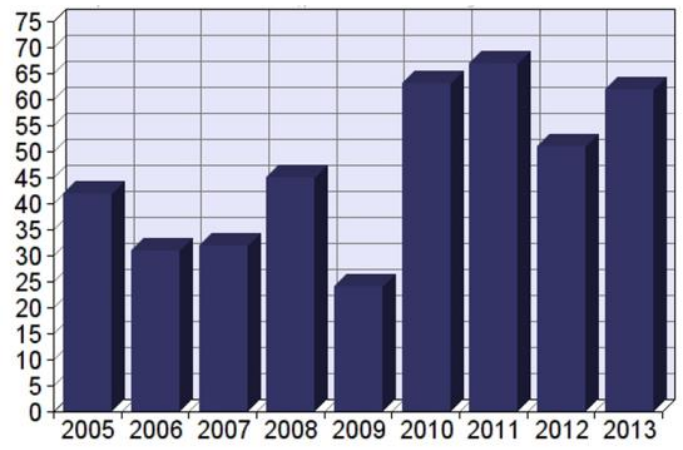

Fig. 1. Chart of the number of incidents with crude oil or petroleum products on the far Eastern Railway.

Thereto, the reasons of $85 \%$ of such incidents are the leakages through the drain device or barrel defects. In this regard, it seems relevant to develop special technical means to eliminate and prevent leakages from rail tank cars.

\section{Elaboration of the flexible liner}

To prevent leakage of hazardous liquid cargoes (in particular oil and petroleum products), it is proposed to use a patented author's design - a flexible liner for a rail tank car, which enables significantly reducing the risks of leakages during transportation by rail [4]. The liner can also be used for increasing the service life of tank cars and reduce their maintenance costs (Figure 2).

Figure 2 shows the layout of a flexible liner for rail tank cars transporting hazardous liquids. The device consists of an envelope 1 with a drain cone 5 and a neck 2 installed on it, longitudinal air channels 7 , transversal air channels 8 , inlet manifold 3 with shut-off valve 4 . For filling air channels with air, the neck 2 has a cutout 9 and a fastening device 6 .

The liner is placed in a tank. The neck 2 is fixed to the hatch of the tank by fixing device 8. The valve 4 opens and firstly air channels 7 and then air channels 8 are filled with air through the inlet manifold 3. As a result, the liner fills the volume of the tank. Valve 4 closes. The transported liquid is poured through the neck 2 . After filling the $2 / 3$ of volume, the valve 4 opens and, under the impact of filling liquid, air is pushed out of the air channels 7 and 8 .

After the regulatory filling of the tank, the liner and then the hatch are hermetically sealed. After the discharge of the transported liquid, the liner is disposed. 

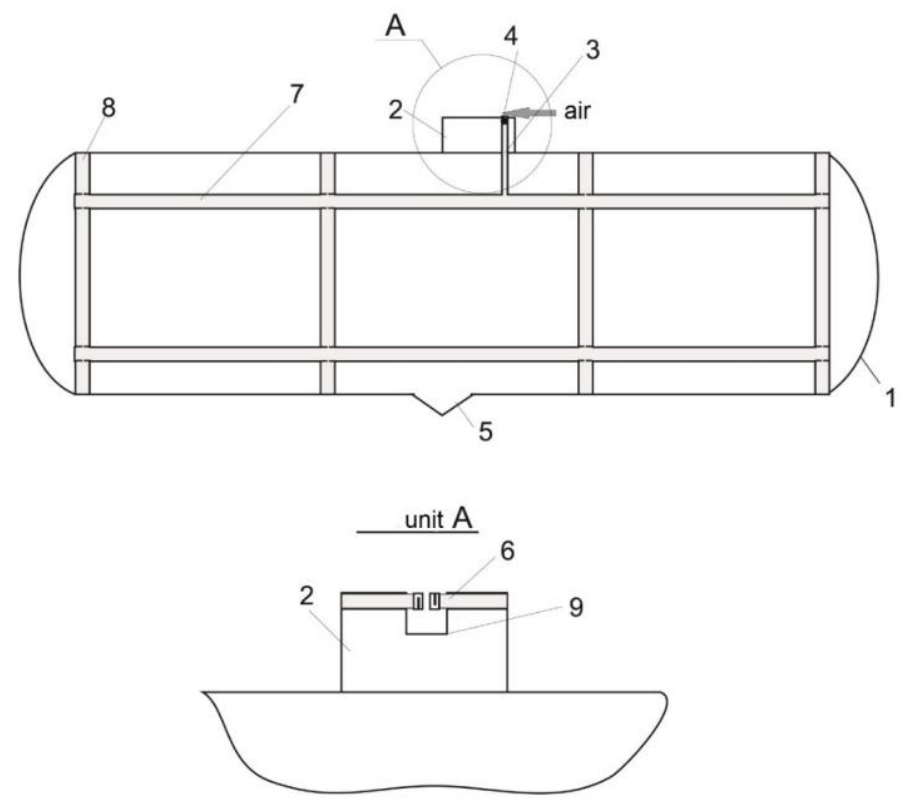

Fig. 2. Flexible liner for rail tank cars.

Flexible liners are made of chemically resistant composite materials that are not susceptible to various types of corrosive media. The installation of flexible liners requires minimal labor and time and can be done by a carrier on his own.

The use of the liner increases the productivity of work during the transportation of liquid products, since when using the liner there is almost no need to clean tanks after discharging, the possibility of harmful effects of corrosive liquids on natural environment is excluded, and the contact of transported liquids with the car tank walls is also excluded.

Since the contact of transported cargo with tank walls is excluded, a tank can further be used for transportation of other types of substances without additional processing and preparation [5].

The weak point of this design was that the structural features of the liner did not allow installing it into tank cars having bottom discharge.

Inside a tank car with bottom discharge, a universal drain device consisting of a bar and a valve is installed, which locks the drain pipe and ensures a bottom discharge of transported liquid cargo.

In this connection, the following aim was posed and solved: creating a flexible liner for the transport of cargos in rail tank cars with bottom discharge, which allows to expand the functionality of the liner and thereby increase the operation productivity when transporting liquid cargos. In order to solve this problem, an additional cylinder shaped hose is installed in a flexible liner having a cylinder shaped container made of membrane.

The diameter of a hose allows to circuit the structure of the drain device of a tank car. The hose is located inside the container of the liner over the hole made at the bottom of the container where the drain device of a tank car should be installed. Such a hose is made of a membrane having varying cross-section with a smaller wall thickness in the place of the drain device valve. 
The lower part of the hose is connected to the liner container by hermetic sealing method, and its upper part is fixed to the upper part of the drain device bar using a fixing device.

An additional hose with the variable cross-section height provided for a liner significantly increases its functionality, because the list of transport carriers, where the liner can be installed, gets larger. Therefore, the liner can be applied not only in tank cars with an upper hatch for pumping the liquid cargo out, but also in tank cars with a bottom discharge.

This development received a positive conclusion report for the Russian Federation patent granting (application No. 2014130833/11(049526), priority of July 24, 2014).

The use of the device leads to a significant increase in the operation performance for the transportation of oil and petroleum products, as well as in the safety of these transportations.

Figure 3 shows the layout of a flexible liner for transportation of liquid cargos in rail tank cars with bottom discharge.

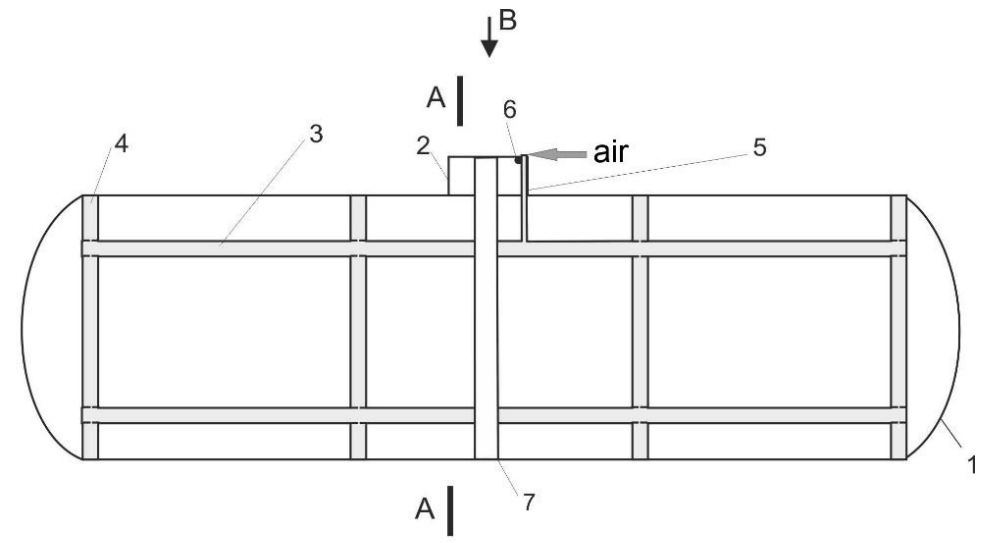

section A-A

view B
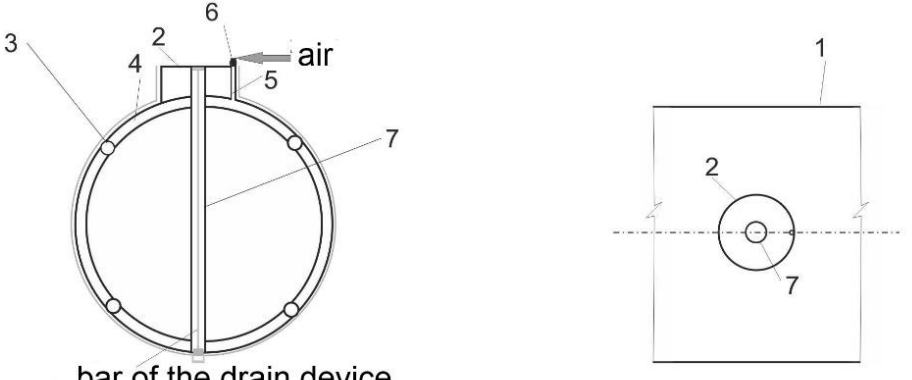

Fig. 3. Layout of flexible liner for transportation of liquid cargos in rail tank cars with bottom discharge.

The liner has a container 1 made of polyethylene (polypropylene) membrane that repeats the internal contours of the tank car, a loading hose 2 located at the top of the container 1 and made with cutouts at the top. The dimensions of the cutouts correspond to the dimensions of 
the fastening and closing elements of the tank hatch. There are horizontal 3 and vertical 4 air channels inside of container that are interconnected with each other. The inlet/outlet air tube 5 with the shut-off valve 6 is installed inside the loading hose 2 with the possibility of communicating with the horizontal air channel 3 of the container 1.

The additional hose 7 is located inside the container 1 of the liner along its height and above the hole placed at the bottom of the container where the drain device of the tank car is supposed to be installed. All parts of the liner are connected with each other by hermetic sealing method. The lower part of the additional hose 7 is connected to the container 1 of the liner by hermetic sealing method. Loading hose 2 is fixed to the hatch of the tank car; the upper part of the additional hose 7 is fixed to the bar of the drain device with the use of fixing devices.

\section{Calculation of the hose of the liner}

Calculation of the wall thickness of the hose of the liner aimed at ensuring the unloading process is performed as an analysis of a thin-walled vessel (shell).

Let us consider this structure as an axisymmetric thin-walled shell, which is under the internal pressure of the liquid weight.

In order to solve the problem stated above, let us apply Laplace's equation to determine stresses in symmetric shells. Let us select an infinitesimally small element of the shell and consider the conditions for its equilibrium (Fig. 4).

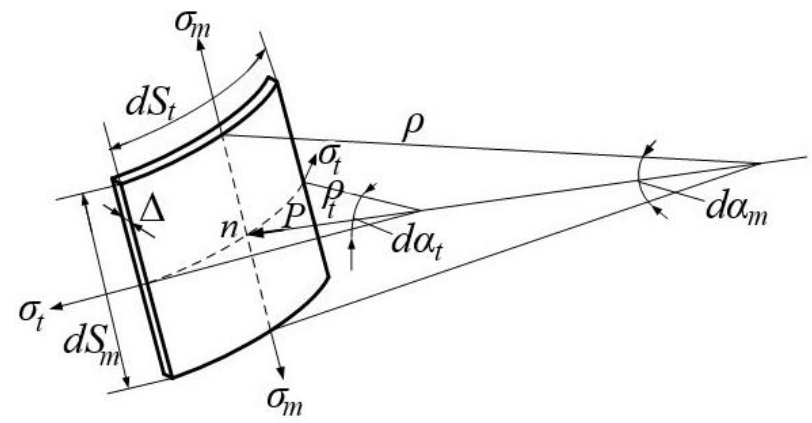

Fig. 4. Forces acting on an infinitesimally small element of the shell.

In meridional and circumferential cross sections, there are no tangential stresses because the load is symmetric. Therefore, there are only principal normal stresses: meridional stress and circumferential stress. Based on the membrane theory, let us assume that the stresses are uniformly distributed over the thickness of the wall. In addition, all dimensions of the shell will be referred to the middle surface of its walls.

The median surface of the shell is a surface of meridional curvature. Forces $\sigma_{m}, \sigma_{t}$ act on the faces of the selected element. The pressure of the liquid $P$ acts on the inner surface of the element. By designing the forces listed above on the normal of the surface, the equilibrium condition for an shell's infinitesimal element is found:

$$
2 \sigma_{m} \Delta d S_{t} \sin \frac{d \alpha_{m}}{2}+2 \sigma_{t} \Delta d S_{m} \sin \frac{d \alpha_{t}}{2}-p d S_{t} d S_{m}=0
$$


Replacing the sinuses in (1) by their arguments (since the angles dam and dat are small) and dividing all the terms of the equation by $\Delta \cdot d S_{t} \cdot d S_{m}$, we obtain:

$$
\sigma_{m} \frac{d \alpha_{m}}{d S_{m}}+\sigma_{t} \frac{d \alpha_{t}}{d S_{t}}=\frac{p}{\Delta}
$$

The curvature degrees of the meridional and circumferential cross sections of the element are $\frac{d \alpha_{m}}{d S_{m}}=\frac{1}{p_{m}}$ and $\frac{d \alpha_{t}}{d S_{t}}=\frac{1}{p_{t}}$ respectively. Substituting these expressions into (2), find:

$$
\frac{\sigma_{m}}{\rho_{m}}+\frac{\sigma_{t}}{\rho_{t}}=\frac{p}{\Delta}
$$

Expression (3) is the Laplace equation, which includes two unknown stresses $\sigma \mathrm{m}$ and $\sigma \mathrm{t}$. The meridional stress $\sigma \mathrm{m}$ is found by forming the equilibrium equation for the forces acting on the cut off part of the shell. The area of the circular cross section of the shell walls is calculated by the formula for the circle area $\mathrm{S}=\pi \mathrm{R} 2$, where $\mathrm{R}$ is the radius of the circumferential cross section. The stresses are distributed uniformly on the area due to the symmetry of the shell and the load about the axis. Consequently,

$$
\sigma_{m} 2 \pi R \Delta \cos \alpha-p \pi R^{2}-Q=0
$$

which obtain:

$$
\sigma_{m}=\frac{P R^{2}+Q}{2 \pi R \Delta \cos \alpha}
$$

where $Q$ - the weight of the part of the vessel and liquid located below the section under consideration; $P$ - the liquid pressure that is the same in all directions and equal to $\gamma h(\gamma-$ bulk density of the liquid, $h$ - the location depth of the point under consideration).

As it was mentioned above, the principal stresses are the circumferential $\sigma \mathrm{t}$ and the meridional $\sigma \mathrm{m}$ stresses. The volume of the third principal stress, located along the normal, can be neglected.

Thus, we assume that the shell material is in a plane stress state. Applying the fourth (energy) theory, let us write the strength condition in the form [6]:

$$
\sigma_{\text {eq }}^{(4)}=\sqrt{\left(\sigma_{t}^{2}-\sigma_{m}^{2}\right)+\sigma_{m}^{2}+\sigma_{t}^{2}} \leq[\sigma]
$$

Due to the circular symmetry of the shell and the axisymmetry of the load, the stresses are identical at all points of the shell. For this reason, we obtain:

$$
\begin{gathered}
\sigma_{t}=\sigma_{m}=\sigma, \quad p=q \\
\sigma=\frac{q R}{2 \Delta}
\end{gathered}
$$

Let us perform checking by the third strength theory: 


$$
\sigma_{\mathrm{eq}}^{(3)}=\sigma_{1}-\sigma_{3} \leq[\sigma]
$$

Taking into account that $\sigma_{2}=\sigma_{m}=0, \sigma_{3}=0$ the strength condition will take the following form:

$$
\begin{gathered}
\sigma_{e q}^{(3)}=\sigma=\frac{q R}{2 \Delta} \leq[\sigma], \\
\Delta=\frac{q R}{2[\sigma]}=\frac{P R}{2[\sigma]},
\end{gathered}
$$

where: $P=P_{0}+\rho g h, \mathrm{P} 0$ is the standard atmospheric pressure equal to 760 millimeters of mercury or 1.013.105 Pascal; $\rho$ is the density of petroleum hydrocarbons (the average value $\rho$ under normal conditions is $700 \mathrm{~kg} / \mathrm{m} 3) ; g$ - is the acceleration of free fall $g=9,8$ $\mathrm{m} / \mathrm{s} 2$; $\mathrm{h}$ is the laying depth of the cylinder in meters

$$
\begin{gathered}
P=1,013 \cdot 10^{5}+700 \cdot 9,8 \cdot 3=3071 \mathrm{~kg} / \mathrm{cm}^{2} \\
\Delta=\frac{q R}{2[\sigma]}=\frac{3071 \cdot 0,075}{2 \cdot 40000}=0,2 \mathrm{~cm}
\end{gathered}
$$

Therefore, in order to provide the rupture of the hose wall and the drain of oil when opening the bottom valve, the thickness of the liner hose wall should be less than $\Delta$, which corresponds to the material taken within the development process.

\section{Conclusion}

Application of the new design of a liner reduces labor costs and time expenditure of preparing rail tank cars for reloading, leads to a significant mitigation of leakage risks of hazardous cargos including oil and petroleum products while transporting by rail, helps to ensure the safety and security of hazardous cargo transportation and minimize its negative impact on the environment.

Application of the liner allows ensuring hermetical containment of a tank car even if a barrel has any minor defects, excludes a contact of cargo with tank walls, which leads to increase in the security of hazardous liquid cargo transportation.

\section{References}

1. Pravila bezopasnosti pri perevozke opasnykh gruzov zheleznodorozhnym transportom, http://www.transinterlog.com/articles /68/page/3/

2. Park tsistern v RF polnost'yu udovletvoryayet potrebnosti v perevozkakh nefti - RZHD,, http://www.oilcapital.ru/transport/172503.html 
3. A.N. Lutsenko, V.D. Katin, Trudy Vserossiyskoy molodezhnoy nauchno-prakticheskoy konferentsii "Nauchno-tekhnicheskiye problemy transporta, promyshlennosti $i$ obrazovaniya» (Izdatel'stvo DVGUPS, Khabarovsk, 2012)

4. A.N. Lutsenko, V.D. Katin, Patent 118273 Rossiyskaya Federatsiya: MPK Ye01R 1/08 (2006.01) Gibkiy vkladysh dlya perevozki gruzov v zheleznodorozhnykh vagonakhtsisternakh (DVGUPS, Khabarovsk, 2012)

5. A.N. Lutsenko, V.D. Katin, Vysokoeffektivnyye tekhnologicheskiye $i$ tekhnicheskiye resheniya dlya preduprezhdeniya i likvidatsii razlivov nefti I nefteproduktov v usloviyakh Dal'nego Vostoka (Aeterna, Ufa, 2016)

6. Ye.KH. Bushman, R.V. Kiselevich, Raschet tonkostennykh rezervuarov: Metodicheskiye ukazaniya na vypolneniye raschetno-proyektirovochnykh rabot (Izd-vo DVGUPS, Khabarovsk, 2003) 